\title{
Brain injury, neuroinflammation and Alzheimer's disease
}

\author{
Joshua J. Breunig ${ }^{1,2 *+}$, Marie-Victoire Guillot-Sestier ${ }^{3 \dagger}$ and Terrence Town ${ }^{3 *}$ \\ ${ }_{1}^{1}$ Regenerative Medicine Institute, Cedars-Sinai Medical Center, Los Angeles, CA, USA \\ 2 Department of Biomedical Sciences, Cedars-Sinai Medical Center, Los Angeles, CA, USA \\ ${ }^{3}$ Department of Physiology and Biophysics, Zilkha Neurogenetic Institute, Keck School of Medicine of the University of Southern California, Los Angeles, CA, USA
}

\section{Edited by:}

Orly Lazarov, The University of

Illinois at Chicago, USA

Reviewed by:

Karl Herrup, Case Western University, USA

Jiawei Zhou, Shanghai Institutes for

Biological Sciences Chinese

Academy of Sciences, China

\section{*Correspondence:}

Joshua J. Breunig, Regenerative

Medicine Institute at Cedars-Sinai

Medical Center, Advanced Health

Sciences Pavilion Building Room

A8109, 8700 Beverly Boulevard, LoS

Angeles, CA 90048, USA

e-mail: joshua.breunig@cshs.org;

Terrence Town, Department of

Physiology and Biophysics, Zilkha

Neurogenetic Institute, Keck School

of Medicine of the University of

Southern California, 1501 San Pablo

Street, Los Angeles, CA

90089-2821, USA

e-mail: ttown@usc.edu

${ }^{t}$ These authors have contributed

equally to this work.
With as many as 300,000 United States troops in Iraq and Afghanistan having suffered head injuries (Miller, 2012), traumatic brain injury (TBI) has garnered much recent attention. While the cause and severity of these injuries is variable, severe cases can lead to lifelong disability or even death. While aging is the greatest risk factor for Alzheimer's disease $(A D)$, it is now becoming clear that a history of TBI predisposes the individual to $A D$ later in life (Sivanandam and Thakur, 2012). In this review article, we begin by defining hallmark pathological features of $A D$ and the various forms of TBI. Putative mechanisms underlying the risk relationship between these two neurological disorders are then critically considered. Such mechanisms include precipitation and 'spreading' of cerebral amyloid pathology and the role of neuroinflammation. The combined problems of TBI and $A D$ represent significant burdens to public health. A thorough, mechanistic understanding of the precise relationship between $T B I$ and $A D$ is of utmost importance in order to illuminate new therapeutic targets. Mechanistic investigations and the development of preclinical therapeutics are reliant upon a clearer understanding of these human diseases and accurate modeling of pathological hallmarks in animal systems.

Keywords: traumatic brain injury, Alzheimer disease, neuroinflammation, chronic traumatic encephalopathy, tauopathy, amyloid-beta peptides, neuronal loss, transgenic rat model

\section{INTRODUCTION TO TRAUMATIC BRAIN INJURY}

It is estimated that as many as 300,000 U.S. troops in Iraq and Afghanistan have suffered head injuries (Miller, 2012). In the general population, roughly 1.7 million brain injuries are reported, leading to more than 52,000 deaths (Faul et al., 2010). The cause and severity of these injuries is variable, but severe cases can lead to lifelong disability or even death. It is estimated that as many as 5.3 million people have traumatic brain injury (TBI)-associated disabilities. Moreover, TBI-associated direct and indirect costs are approximated to be more than 75 billion dollars a year (Coronado et al., 2012). Beyond the effects of acute injury, troubling new findings indicate that even minor brain injury can predispose to neurodegeneration and dementia in later life. While aging is generally accepted to be the greatest risk factor for Alzheimer's disease $(\mathrm{AD})$, it is now widely recognized that a history of TBI is a key risk factor for the disease (Sivanandam and Thakur, 2012). For example, incidence of AD is significantly increased in individuals who have a documented history of TBI (Sivanandam and Thakur, 2012).

\section{ALZHEIMER'S DISEASE: SEVERITY OF THE PROBLEM}

Largely due to population-wide increases in life-span, $\mathrm{AD}$ is rapidly becoming the public health crisis of our time. There are currently over three million Americans afflicted with the disease, a figure that is projected to increase to nearly nine million Americans and over 100 million world-wide by 2050 (Brookmeyer et al., 2007). Unfortunately, AD prevalence will continue to rise in parallel with the aging of the world's populations unless something is done (Brookmeyer et al., 2007). Because of the long prodromal phase leading to clinical manifestation of $\mathrm{AD}$, TBI early in life would not impact $\mathrm{AD}$ diagnosis until decades later. At that point, the full impact of TBI-induced AD on soldiers and their families would place an unprecedented burden on the United States public health system.

$\mathrm{AD}$ is a devastating, mind-robbing neurodegenerative disease that is defined at autopsy by $\beta$-amyloid plaques [chiefly comprised of amyloid- $\beta$ (A $\beta$ ) peptides], neurofibrillary tangles (NFTs), and widespread loss of cortical neurons (Selkoe, 2001). Although these features are pathognomonic of $\mathrm{AD}$, Alois Alzheimer himself originally identified a third pathology-inflammation of the brain's glial supporting cells (Alzheimer et al., 1995). While one interpretation is that all forms of neuroinflammation are deleterious for the aging brain, we have hypothesized that re-balancing inflammatory signals as opposed to shutting them off completely might limit AD progression (Town et al., 2005; Weitz and Town, 2012). In that vein, it has been shown that genetic or pharmacologic blockade of a key pathway responsible for suppressing inflammation, the transforming growth factor-beta 
(TGF- $\beta$ )-Smad 2/3 signaling cascade, reduces AD-like pathology. Specifically, peripheral blockade of the TGF- $\beta$-Smad $2 / 3$ signaling pathway leads to brain penetration of peripheral macrophages and amelioration of the defining pathology of $\mathrm{AD}-\beta$-amyloid plaques - in the Tg2576 transgenic mouse model of cerebral amyloidosis (Town et al., 2008; Rezai-Zadeh et al., 2009; Town, 2009; Gate et al., 2010). These results have importance, because there is currently no treatment or cure available for $\mathrm{AD}$.

\section{TRAUMATIC BRAIN INJURY AND ALZHEIMER'S DISEASE RISK}

The term "TBI" encompasses a wide variety of traumas. In fact, any form of brain injury is broadly classified as a TBI. Nevertheless, brain traumas can grossly be divided into two categories: (1) closed head injuries (where a rapid deceleration or blow to the head causes brain damage) or (2) penetrating head injuries (caused by a foreign object piercing the skull). Closed head injuries can come in the form of skull fractures, brain contusions caused by brain-skull impact, hematomas, and diffuse axonal injuries brought on by shearing forces. Notably, closed head injuries associated with concussions from contact sports and shockwave blasts from improvised explosive devices have garnered much recent attention. TBIs may range from mild to severe, with about $75 \%$ of injuries coming in the form of concussions or other mild TBIs (Hyder et al., 2007).

Pathological analyses of human TBI tissue have led to variable conclusions as compared with animal model studies. This is likely attributable to both the heterogeneity of the injury itself and methods of tissue collection. Nonetheless, several broad patterns of results have emerged. One of the most notable findings concerns the association between $\mathrm{AD}$ pathological features and TBI. For example, by examining cortical regions from TBI patients with survival times ranging from $4 \mathrm{~h}$ to several years, increased expression of the amyloid precursor protein (APP; which gives rise to the $A \beta$ peptides that comprise senile plaques) has been demonstrated in the acute response to brain injury (Roberts et al., 1994; Graham et al., 1996). Another study reported that APP could be used as a general marker for axonal injury in human post-mortem material (Gentleman et al., 1993). More recently, $\mathrm{A} \beta$ deposits have been observed in roughly a third of TBI patients and as early as $2 \mathrm{~h}$ after injury (Ikonomovic et al., 2004). Overall, the conclusions were that $A \beta$ plaques developed rapidly after injury, while NFTs formed during the chronic phase of disease (Ikonomovic et al., 2004). Follow-up studies have documented that severe TBI can induce A $\beta 42$ (widely regarded as the more pathogenic species of the peptide), potentially leading to increased risk of AD later in life (DeKosky et al., 2007).

A very recent study examined survivors of a single TBI 1-47 years after the trauma, and reported that NFTs and A $\beta$ pathology were present in approximately one-third of these patients. Such findings demonstrate the long-term consequences of a single TBI event (Johnson et al., 2012). On the other hand, more chronic, mild TBIs are associated with a distinct pathology, termed chronic traumatic encephalopathy (CTE) (McKee et al., 2010). Notably in CTE, NFTs are typically found with gliosis, but $\beta$-amyloid deposits are less obvious as compared with $\mathrm{AD}$ (Costanza et al., 2011). Unfortunately, CTE has become increasingly recognized in war veterans, boxers, and athletes in other impact sports (McKee et al., 2010; Costanza et al., 2011; Gavett et al., 2011; Stern et al., 2011; Goldstein et al., 2012; Miller, 2012; Shively et al., 2012; McKee et al., 2013). These troubling findings are no doubt cause for concern.

\section{MECHANISMS TO ACCOUNT FOR THE RISK RELATIONSHIP BETWEEN TRAUMATIC BRAIN INJURY AND ALZHEIMER'S DISEASE}

As mentioned above, TBI is a strong epigenetic risk factor for development of $\mathrm{AD}$ later in life. Strikingly, several defining $\mathrm{AD}$ pathological hallmarks have been observed following TBI in patient brains and in numerous TBI animal models. In addition to neuronal and synaptic loss (Kotapka et al., 1992; Smith et al., 1997; Maxwell et al., 2010), AD-characteristic lesions include accumulation of $\mathrm{A} \beta$ peptides, hyper-phosphorylated tau protein (the principle component of NFTs), and persistent microgliosis. A key question that arises from these observations is: what are the mechanism(s) responsible for development of $\mathrm{AD}$ in patients with a clinical history of TBI?

\section{A $\beta$ PATHOLOGY AND SPREADING}

$\mathrm{A} \beta$ deposits and widespread axonal $\mathrm{A} \beta$ accumulation have been found in patients' brains shortly after TBI (Roberts et al., 1991, 1994; Graham et al., 1995; Smith et al., 2003a; Ikonomovic et al., 2004; Uryu et al., 2007) and are still present many years after a single severe head trauma or repetitive mild TBIs (Tokuda et al., 1991; Johnson et al., 2012). Remarkably, following TBI, the major type of soluble and deposited $A \beta$ peptide found in patients' brains is $A \beta 42$, well-known for its neurotoxicity and high propensity to aggregate (Gentleman et al., 1997; DeKosky et al., 2007). Several studies have described dramatic APP accumulation in swollen axons after TBI, which would provide an abundant source of substrate for A $\beta$ production (Gentleman et al., 1993; Sherriff et al., 1994; Gorrie et al., 2002). Axonal swelling observed after TBI has been ascribed to cytoskeletal alteration and interruption of protein transport (Maxwell et al., 2003).

In an attempt to clarify mechanisms of plaque appearance after brain trauma, several non-transgenic rodent and rabbit models have been utilized. While these animal models have proved useful to characterize axonal $A \beta$ accumulation after TBI, wildtype rodents and rabbits did not manifest cerebral $\beta$-amyloid plaques. This is likely owed to the fact that these TBI animal models have relatively low abundance of brain endogenous $\mathrm{A} \beta$ species that do not reach a critical threshold for aggregation (Lewen et al., 1995; Pierce et al., 1996; Bramlett et al., 1997; Hoshino et al., 1998; Iwata et al., 2002; Stone et al., 2002; Hamberger et al., 2003; Abrahamson et al., 2006). Another strategy has been to rely on transgenic mice that develop agedependent $A \beta$ plaque deposition. Unlike their wild-type counterparts, these animal models have contributed to our understanding of mechanisms of $\mathrm{A} \beta$ deposition after TBI. Like their nontransgenic counterparts, these transgenic mice manifest axonal $A \beta$ post-TBI. However, and unlike wild-type animals, these transgenics demonstrate enhanced accumulation of $\beta$-amyloid plaques after TBI (Smith et al., 1998, 1999; Hartman et al., 2002; Uryu et al., 2002; Abrahamson et al., 2009). Moreover, studies in various animal models indicate that expression of amyloidogenic 
$\beta$ - and $\gamma$-secretases and their substrate-APP - is increased after TBI, suggesting that $\mathrm{A} \beta$ peptides are generated de novo following brain trauma (Cribbs et al., 1996; Blasko et al., 2004; Chen et al., 2004; Nadler et al., 2008; Loane et al., 2009; Tran et al., 2011a; Yu et al., 2012). Thus, long-lasting elevation of A $\beta$ following TBI is likely to result in $\mathrm{A} \beta$ pathology, up to and including senile plaque formation.

An important related concept is the idea of $A \beta$ pathology "spreading." Interestingly, studies from Mathias Jücker's laboratory and others have shown that intracerebral infusion of brain extracts containing aggregated $A \beta$ can initiate $A \beta$ deposition in brains of APP transgenic mice (Kane et al., 2000; Walker et al., 2002; Meyer-Luehmann et al., 2006; Eisele et al., 2009). Furthermore, it has been shown that $A \beta$ seeds can migrate between axonally interconnected areas, suggesting that $\mathrm{A} \beta$ peptides can spread from the site of injection to other brain regions (Walker et al., 2002; Eisele et al., 2009). These results provide a potential mechanism for TBI-induced amyloid pathology spreading from the site of the TBI to other brain areas classically associated with $\mathrm{AD}$-type pathological lesions but not directly subjected to the TBI.

TBI has also been shown to induce tauopathy. In that regard, it is important to note that a similar process has been described for spreading of NFTs by axonal transport after injection of abnormally folded tau filaments into a mouse model of cerebral amyloidosis (Clavaguera et al., 2009). Such findings suggest the possibility of abnormal tau protein seeds that spread following TBI. These results are summarized in Table $\mathbf{1 .}$

\section{NEUROINFLAMMATION}

In patients' brains as well as in experimental animal models, TBI has been associated with microglial activation (Carbonell and Grady, 1999; Koshinaga et al., 2000; Davalos et al., 2005; Morganti-Kossmann et al., 2007; Ojo et al., 2013). The early phase of microglial activation in response to brain injury is accompanied by increased levels of interleukin-10 and TGF- $\beta$, which are generally regarded as anti-inflammatory cytokines that are capable of mediating neural protection and regeneration (Knoblach and Faden, 1998; Csuka et al., 1999; Tyor et al., 2002). Anti-inflammatory microglia with phagocytic properties have the potential to clear $A \beta$ species and $\beta$-amyloid plaques; remarkably, $\mathrm{A} \beta$-containing microglia have been found in association with plaques after TBI (Chen et al., 2009). Such findings suggest that microglia play a principle role in remodeling cerebral amyloid following brain injury (Giunta et al., 2008).

Depending on their activation state, microglia can be deleterious or beneficial in the context of cerebral amyloid deposition (Town et al., 2005; Weitz and Town, 2012). However, in rodents, primates and humans, microglial activation persists for months or even years after TBI, indicative of chronic neuroinflammation (Smith et al., 1997; Csuka et al., 2000; Gentleman et al., 2004; Nagamoto-Combs et al., 2007; Nagamoto-Combs and Combs, 2010; Ramlackhansingh et al., 2011; Shitaka et al., 2011). Chronic cerebral inflammation is typically associated with increased abundance of proinflammatory cytokines such as IL- $1 \beta$, TNF- $\alpha$ and IL-6 and an array of chemokines (Stover et al., 2000; MorgantiKossmann et al., 2001; Rothwell, 2003; Dietrich et al., 2004;
Israelsson et al., 2008). This phenotype is remarkably similar to the low-level pro-inflammatory, chronic microglial activation state that occurs in $\mathrm{AD}$ and ultimately fails to restrict amyloid deposition. Additionally, it has been extensively reported that aging microglia undergo structural deterioration and cellular senescence, which likely predicts poor $\mathrm{A} \beta$ clearance aptitude (Flanary and Streit, 2004; Fiala et al., 2005; Hickman et al., 2008; Njie et al., 2012). Furthermore, TBI is classically followed by oxidative stress and hypoxia, which are known to stimulate microglia and astrocytes and induce release of IL- $1 \beta$, TNF- $\alpha$, interferon- $\gamma$ and IL- 6 (Luth et al., 2001). These pro-inflammatory cytokines can stimulate $\gamma$-secretase activity and enhance APP levels and amyloidogenic APP processing, potentially exacerbating $A \beta$ pathology (Tamagno et al., 2003; Blasko et al., 2004; Liao et al., 2004; Rogers et al., 2008; Agostinho et al., 2010). In addition, increased expression of presenilin-1 and nicastrin in TBI-activated microglia has been described in mice, reinforcing the probable implication of microglia in post-injury $\mathrm{A} \beta$ pathology (Liao et al., 2004; Nadler et al., 2008). Altogether, these mechanisms could perpetrate a chronic vicious cycle involving inefficient activation of microglia, cerebral $A \beta$ accumulation and spreading, and development of AD-type pathology. In summary then, the early inflammatory response after TBI may negatively impact $\mathrm{AD}$ pathology later on.

\section{ANIMAL MODELS: PRESENT AND FUTURE}

The development of clinically-relevant animal models is critically important to enable future study at the intersection of $\mathrm{TBI}$ and $\mathrm{AD}$ research. Animal models of $\mathrm{AD}$ fail to exhibit some of the key pathological earmarks of the human syndrome, even after significant brain injury (Uryu et al., 2002; Tran et al., 2011a,b). For example, one of the principle symptoms lacking in transgenic mouse models constructed with mutations that cause early-onset familial $\mathrm{AD}$ is fulminant neuronal loss (Duyckaerts et al., 2008). For while most transgenic mouse models display amyloid deposition, and some exhibit tau pathology, almost all do not have appreciable neuronal death (Duyckaerts et al., 2008). For instance, the principle readouts after $\mathrm{TBI}$ in a widely-used mouse model of $\mathrm{AD}$, the $3 \times \mathrm{Tg}-\mathrm{AD}$ mouse, consist primarily of hyperphosphorylated tau and $\beta$-amyloid plaques, because the model does not allow insight into the widespread cortical neuronal loss observed in the human disease (Tran et al., 2011a).

By contrast, we have recently published a novel rat transgenic model of $\mathrm{AD}$, line TgF344-AD. This transgenic line expresses mutant human APP and presenilin-1, which are each independent genetic causes of early-onset familial AD. Notably, this rat displays the full spectrum of human $\mathrm{AD}$ hallmarks, including cerebral amyloidosis, tauopathy, gliosis, and most importantly, large-scale apoptotic loss of neurons in cortical and hippocampal regions. Moreover, these animals display significant agedependent cognitive disturbance (Cohen et al., 2013). The precise reason(s) for the differences between this new transgenic rat model and analogous mouse models are unclear. Rats are fourto-five million years closer to humans on the evolutionary tree than mice. In addition, rats, like humans and unlike mice, have all six tau isoforms. Therefore, rats have a physiology 
Table 1 | Alzheimer's disease-type lesions induced by various TBls in humans and in animal models.

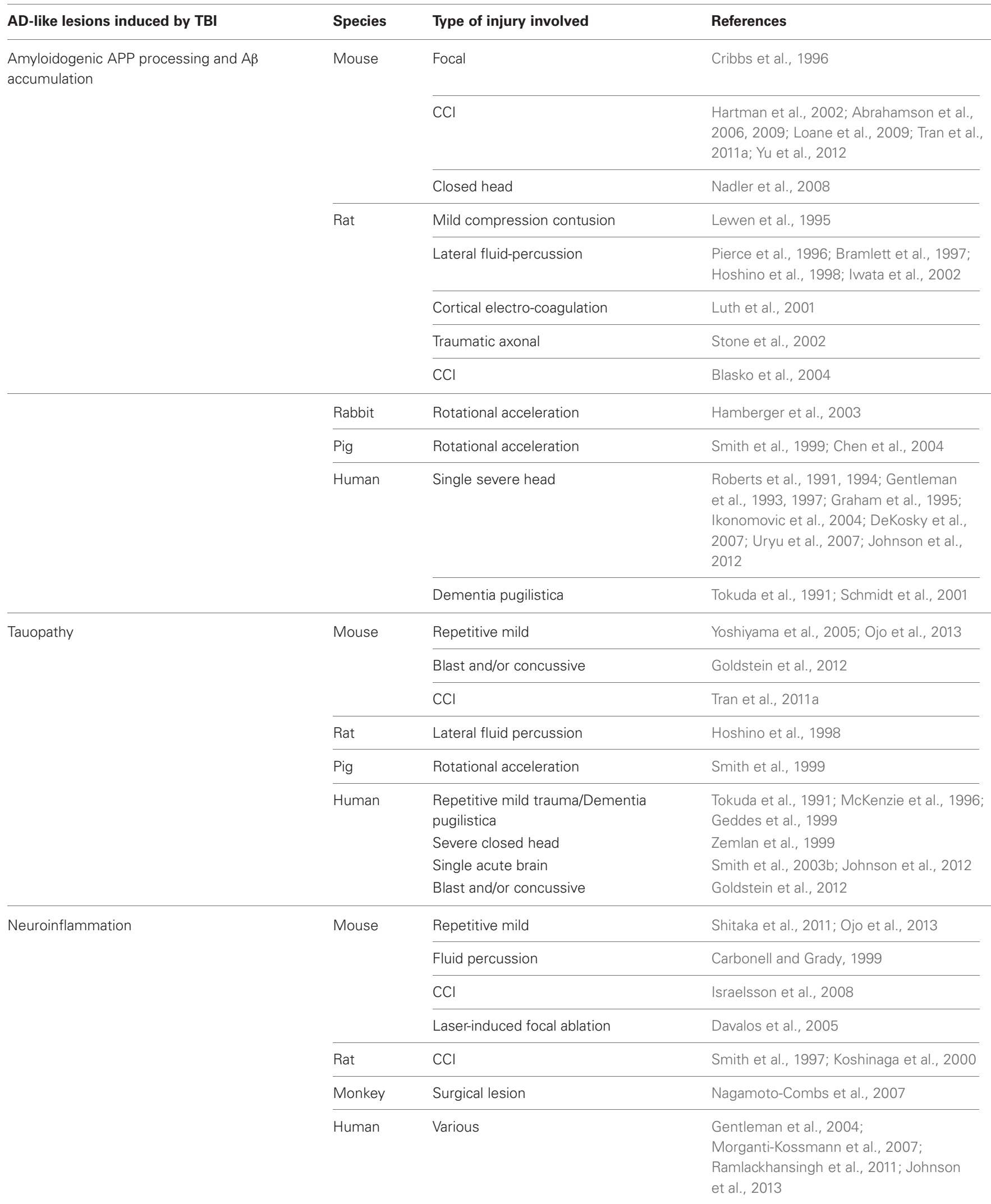


Table 1 | Continued

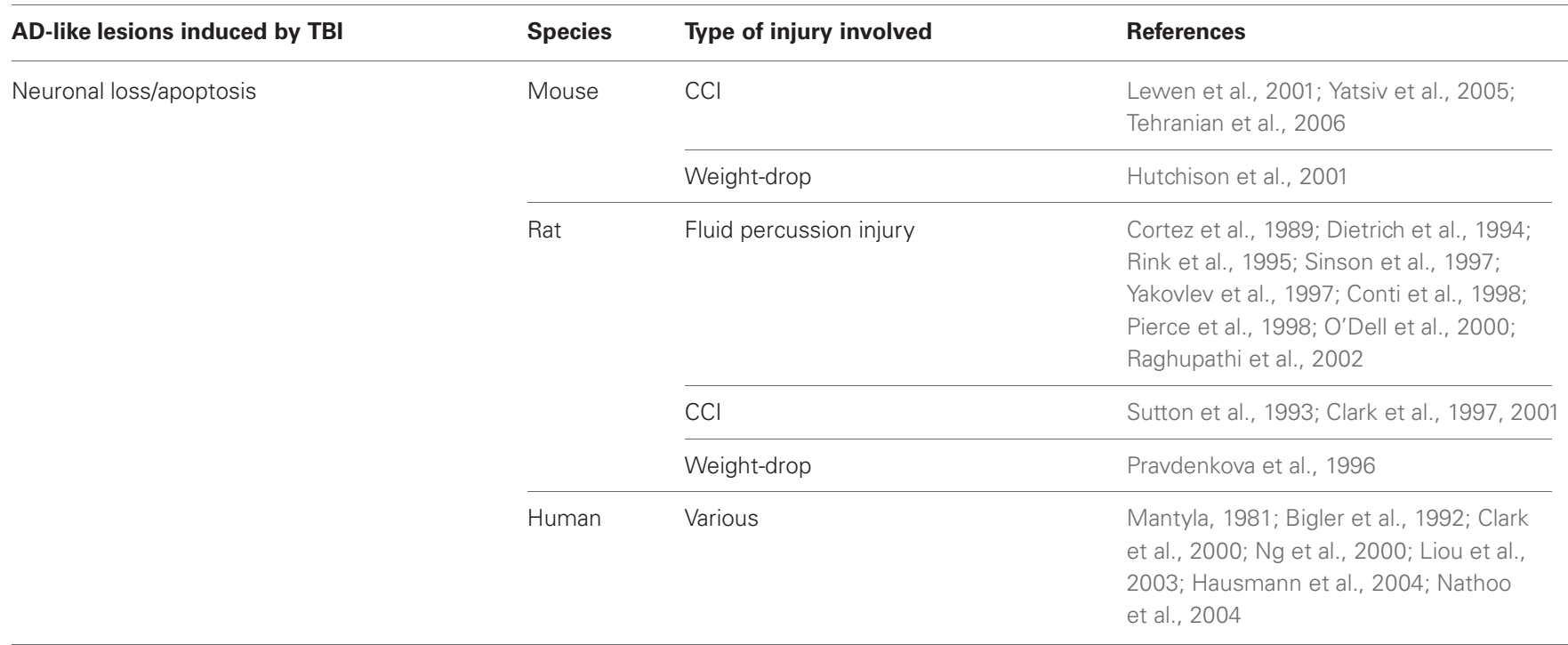

AD, Alzheimer's disease; CCl, controlled cortical impact.

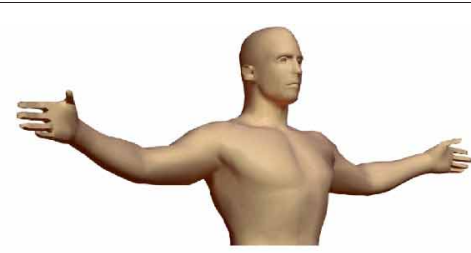

Man

Tau isoforms

Tauopathy

Cerebral

Amyloidosis

Neuronal

Death

\section{Potential for} TBI/CTE Investigation

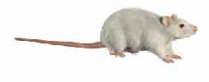

AD Rat

2-3 years

6

$+$

$+$

$+$

high

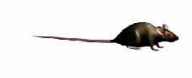

AD Mouse
$>70$ years

6

2-3 years

3

$-$

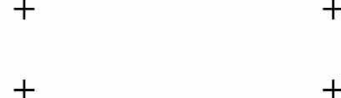

$+$

limited to post

mortem

\section{limited by \\ lack of neuronal \\ death}

FIGURE 1 | Modeling the risk relationship between traumatic brain injury and Alzheimer's disease. Presence (+) or absence (-) of various pathological features is indicated. AD, Alzheimer's disease; TBI, Traumatic Brain Injury; CTE, Chronic Traumatic Encephalopathy.

that is more similar to the human and may be more permissive to neurodegenerative disease. For these reasons, it will be highly informative to test whether TBI precipitates earlier neuronal loss and tauopathy in this line of rats. Moreover, the behavioral correlates of neuronal damage and loss can be carefully related in a way that more closely approximates human trauma and associated cognitive decline. Specifically, if TBI leads to neuronal loss in the long term, these rats might be used to determine if therapeutic intervention(s) could be introduced to attenuate or prevent neurodegeneration and cognitive impairment (Figure 1).

\section{CONCLUSIONS AND FUTURE DIRECTIONS}

The correlation between brain injury and neurodegenerative disease is now well-established (Szczygielski et al., 2005; Shively et al., 2012). The combined problems of TBI and AD will become 
increasingly significant burdens to society. Both diseases will require early identification in the form of imaging or biomarkers to allow for therapeutic intervention at the earliest possible stages. Unfortunately, a treatment or therapy does not currently exist for either disease. A thorough, mechanistic understanding of the precise relationship between TBI and AD is of utmost importance in order to illuminate new therapeutic targets. However, as we have highlighted, key questions remain regarding the precise mechanisms linking the many forms of brain injury with precipitation of AD-type neurodegeneration.

These mechanistic investigations and the development of pre-clinical therapeutics will rely critically on a clearer understanding of both human pathologies. A key limiting factor is the large gap in our knowledge of the link between postmortem observations in humans after TBI with animal model systems. Part of the uncertainty can be attributed to limitations inherent to experimental models of TBI. Therefore, it is

\section{REFERENCES}

Abrahamson, E. E., Ikonomovic, M. D., Ciallella, J. R., Hope, C. E., Paljug, W. R., Isanski, B. A., et al. (2006). Caspase inhibition therapy abolishes brain traumainduced increases in Abeta peptide: implications for clinical outcome. Exp. Neurol. 197, 437-450. doi: $\quad 10.1016 /$ j.expneurol.2005. 10.011

Abrahamson, E. E., Ikonomovic, M. D., Dixon, C. E., and DeKosky, S. T. (2009). Simvastatin therapy prevents brain trauma-induced increases in beta-amyloid peptide levels. Ann. Neurol. 66, 407-414. doi: 10.1002/ana.21731

Agostinho, P., R. Cunha, A., and Oliveira, C. (2010). Neuroinflammation, oxidative stress and the pathogenesis of Alzheimer's disease. Curr. Pharm. Des. 16, 2766-2778. doi: 10.2174/ 138161210793176572

Alzheimer, A., Stelzmann, R. A., Schnitzlein, H. N., and Murtagh, F. R. (1995). An English translation of Alzheimer's 1907 paper, "Uber eine eigenartige Erkankung der Hirnrinde." Clin. Anat. 8, 429-431. doi: 10.1002/ca. 980080612

Bigler, E. D., Kurth, S. M., Blatter, D., and Abildskov, T. J. (1992). Degenerative changes in traumatic brain injury: post-injury magnetic resonance identified ventricular expansion compared to pre-injury levels. Brain Res. Bull. 28, 651-653. doi: 10.1016/0361-9230 (92)90119-I

Blasko, I., Beer, R., Bigl, M., Apelt, J., Franz, G., Rudzki, D., et al. (2004). Experimental traumatic brain injury in rats stimulates the expression, production and activity of Alzheimer's disease beta-secretase (BACE-1). J. Neural Transm. 111, 523-536. doi: 10.1007/ s00702-003-0095-6

Blasko, I., Stampfer-Kountchev, M., Robatscher, P., Veerhuis, R., Eikelenboom, P., and GrubeckLoebenstein, B. (2004). How chronic inflammation can affect the brain and support the development of Alzheimer's disease in old age: the role of microglia and astrocytes. Aging Cell 3, 169-176. doi: $\quad 10.1111 / \mathrm{j} .1474-9728.2004$. 00101. $\mathrm{x}$

Blennow, K., Hardy, J., and Zetterberg, H. (2012). The neuropathology and neurobiology of traumatic brain injury. Neuron 76, 886-899. doi: $\quad 10.1016 /$ j.neuron.2012. 11.021

Bramlett, H. M., Kraydieh, S., Green, E. J., and Dietrich, W. D. (1997). Temporal and regional patterns of axonal damage following traumatic brain injury: a beta-amyloid precursor protein immunocytochemical study in rats. J. Neuropathol. Exp. Neurol. 56, 1132-1141. doi: 10.1097/00005072-19971000000007

Brookmeyer, R., Johnson, E., ZieglerGraham, K., and Arrighi, H. M. (2007). Forecasting the global burden of Alzheimer's disease. Alzheimers Dement 3, 186-191. doi: 10.1016/j.jalz.2007. 04.381

Carbonell, W. S., and Grady, M. S. (1999). Regional and temporal characterization of neuronal, glial, and axonal response after traumatic brain injury in the mouse. Acta Neuropathol. 98, 396-406. doi: $10.1007 / \mathrm{s} 004010051100$ expected that more precise modeling of pathological hallmarks in animal models will allow us to fill the knowledge gap. Specifically, it will be critical to develop models that accurately mimic the forces impacting the human brain under a variety of circumstances (Morales et al., 2005; Blennow et al., 2012).

\section{ACKNOWLEDGMENTS}

This work was supported by National Institutes of Health Grants 5R00AG029726-04 and 1R01NS076794-01 from the NIA and the NINDS (to Terrence Town), an Alzheimer's Association Zenith Fellows Award ZEN-10-174633 (to Terrence Town), and an American Federation of Aging Research/Ellison Medical Foundation Julie Martin Mid-Career Award in Aging Research M11472 (to Terrence Town). We would like to thank Tara Weitz and David Gate (University of Southern California) for helpful discussion of this work.

Chen, X. H., Johnson, V. E., Uryu, K., Trojanowski, J. Q., and Smith, D. H. (2009). A lack of amyloid beta plaques despite persistent accumulation of amyloid beta in axons of long-term survivors of traumatic brain injury. Brain Pathol. 19 , 214-223. doi: 10.1111/j.1750-3639. 2008.00176.x

Chen, X. H., Siman, R., Iwata, A. Meaney, D. F., Trojanowski, J. Q. and Smith, D. H. (2004). Long-term accumulation of amyloid-beta, beta-secretase, presenilin-1, and caspase- 3 in damaged axons following brain trauma. Am. J. Pathol. 165, 357-371. doi: 10.1016/S00029440(10)63303-2

Clark, R. S., Kochanek, P. M., Adelson, P. D., Bell, M. J., Carcillo, J. A., Chen, M., et al. (2000). Increases in bcl2 protein in cerebrospinal fluid and evidence for programmed cell death in infants and children after severe traumatic brain injury. J. Pediatr. 137, 197-204. doi: $10.1067 / \mathrm{mpd}$. 2000.106903

Clark, R. S., Kochanek, P. M., Dixon, C. E., Chen, M., Marion, D. W., Heineman, S., et al. (1997). Early neuropathologic effects of mild or moderate hypoxemia after controlled cortical impact injury in rats. J. Neurotrauma 14, 179-189. doi: 10.1089/neu.1997.14.179

Clark, R. S. B., Chen, M., Kochanek, P. M., Watkins, S. C., Jin, K. L., Draviam, R., et al. (2001). Detection of single- and doublestrand DNA breaks after traumatic brain injury in rats: comparison of in situ labeling techniques using DNA polymerase I, the Klenow fragment of DNA polymerase I, and terminal deoxynucleotidyl transferase. J. Neurotrauma 18, 675-689. doi:

7627

Clavaguera, F., Bolmont, T., Crowther, R. A., Abramowski, D., Frank, S., Probst, A., et al. (2009). Transmission and spreading of tauopathy in transgenic mouse brain. Nat. Cell Biol. 11, 909-913. doi: 10.1038/ncb1901

Cohen, R. M., Rezai-Zadeh, K., Weitz T. M., Rentsendorj, A., Gate, D., Spivak, I., et al. (2013). A transgenic Alzheimer rat with plaques, tau pathology, behavioral impairment, oligomeric abeta, and Frank neuronal loss. J. Neurosci. 33, 6245-6256. doi: 10.1523/ JNEUROSCI.3672-12.2013

Conti, A. C., Raghupathi, R. Trojanowski, J. Q., and McIntosh, T. K. (1998). Experimental brain injury induces regionally distinct apoptosis during the acute and delayed post-traumatic period. J. Neurosci. 18, 5663-5672.

Coronado, V. G., McGuire, L. C., Faul, M., Sugerman, D. E., and Pearson, W. S. (2012). "Traumatic brain injury epidemiology and public health issues," in Brain Injury Medicine: Principles and Practice, 84. Cortez, S. C., McIntosh, T. K., and Noble, L. J. (1989). Experimental fluid percussion brain injury: vascular disruption and neuronal and glial alterations. Brain Res. 482, 271-282. doi: 10.1016/0006-8993 (89)91190-6

Costanza, A., Weber, K., Gandy, S., Bouras, C., Hof, P. R., Giannakopoulos, P., et al. (2011). Review: Contact sport-related chronic traumatic encephalopathy in the elderly: clinical expression and structural substrates. Neuropathol. Appl. Neurobiol. 37, 
570-584. doi: 10.1111/j.1365-2990. 2011.01186.x

Cribbs, D. H., Chen, L. S., Cotman, C. W., and LaFerla, F. M. (1996). Injury induces presenilin-1 gene expression in mouse brain. Neuroreport 7, 1773-1776. doi: 10.1097/00001756199607290-00016

Csuka, E., Hans, V. H., Ammann, E., Trentz, O., Kossmann, T., and Morganti-Kossmann, M. C. (2000). Cell activation and inflammatory response following traumatic axonal injury in the rat. Neuroreport 11, 2587-2590. doi: 10.1097/00001756200008030-00047

Csuka, E., Morganti-Kossmann, M. C., Lenzlinger, P. M., Joller, H., Trentz, O., and Kossmann, T. (1999). IL-10 levels in cerebrospinal fluid and serum of patients with severe traumatic brain injury: relationship to IL-6, TNF-alpha, TGF-beta1 and blood-brain barrier function. J. Neuroimmunol. 101, 211-221. doi: $\quad 10.1016 / S 0165-5728(99)$ 00148-4

Davalos, D., Grutzendler, J., Yang, G., Kim, J. V., Zuo, Y., Jung, S., et al. (2005). ATP mediates rapid microglial response to local brain injury in vivo. Nat. Neurosci. 8, 752-758. doi: 10.1038/nn1472

DeKosky, S. T., Abrahamson, E. E., Ciallella, J. R., Paljug, W. R., Wisniewski, S. R., Clark, R. S., et al. (2007). Association of increased cortical soluble abeta42 levels with diffuse plaques after severe brain injury in humans. Arch. Neurol. 64, 541-544. doi: 10.1001/archneur.64. 4.541

Dietrich, W. D., Alonso, O., Busto, R., Globus, M. Y., and Ginsberg, M. D. (1994). Post-traumatic brain hypothermia reduces histopathological damage following concussive brain injury in the rat. Acta Neuropathol. 87, 250-258. doi: 10.1007/BF00296740

Dietrich, W. D., Chatzipanteli, K., Vitarbo, E., Wada, K., and Kinoshita, K. (2004). The role of inflammatory processes in the pathophysiology and treatment of brain and spinal cord trauma. Acta Neurochir. Suppl. 89, 69-74. doi: 10.1007/978-3-70910603-7_9

Duyckaerts, C., Potier, M. C., and Delatour, B. (2008). Alzheimer disease models and human neuropathology: similarities and differences. Acta Neuropathol. 115, 5-38. doi: 10.1007/s00401-0070312-8

Eisele, Y. S., Bolmont, T., Heikenwalder, M., Langer, F., Jacobson, L. H., Yan, Z. X., et al. (2009). Induction of cerebral beta-amyloidosis: intracerebral versus systemic Abeta inoculation. Proc. Natl. Acad. Sci. U.S.A. 106, 12926-12931. doi: 10.1073/ pnas.0903200106

Faul, M., Xu, L., Wald, M. M., and Coronado, V. G. (2010). Traumatic Brain Injury in the United States: Emergency Department Visits, Hospitalizations, and Deaths. Centers for Disease Control and Prevention, National Center for Injury Prevention and Control. Atlanta (GA).

Fiala, M., Lin, J., Ringman, J., Kermani-Arab, V., Tsao, G., Patel, A., et al. (2005). Ineffective phagocytosis of amyloid-beta by macrophages of Alzheimer's disease patients. J. Alzheimers Dis. 7, 221-232. discussion: 255-262.

Flanary, B. E., and Streit, W. J. (2004). Progressive telomere shortening occurs in cultured rat microglia, but not astrocytes. Glia 45, 75-88. doi: 10.1002/glia.10301

Gate, D., Rezai-Zadeh, K., Jodry, D., Rentsendorj, A., and Town, T. (2010). Macrophages in Alzheimer's disease: the blood-borne identity. J. Neural Transm. 117, 961-970. doi: 10.1007/s00702-0100422-7

Gavett, B. E., Stern, R. A., and McKee A. C. (2011). Chronic traumatic encephalopathy: a potential late effect of sport-related concussive and subconcussive head trauma. Clin. Sports Med. 30, 179-188, xi. doi: 10.1016/j.csm.2010.09.007

Geddes, J. F., Vowles, G. H., Nicoll, J. A., and Revesz, T. (1999). Neuronal cytoskeletal changes are an early consequence of repetitive head injury. Acta Neuropathol. 98, 171-178. doi: 10.1007/s004010051066

Gentleman, S. M., Greenberg, B. D., Savage, M. J., Noori, M., Newman, S. J., Roberts, G. W., et al. (1997). A beta 42 is the predominant form of amyloid beta-protein in the brains of short-term survivors of head injury. Neuroreport 8, 1519-1522. doi: 10.1097/ 00001756-199704140-00039

Gentleman, S. M., Leclercq, P. D., Moyes, L., Graham, D. I., Smith, C., Griffin, W. S., et al. (2004). Long-term intracerebral inflammatory response after traumatic brain injury. Forensic Sci. Int. 146, 97-104. doi: $\quad 10.1016 /$ j.forsciint.2004. 06.027

Gentleman, S. M., Nash, M. J., Sweeting, C. J., Graham, D. I., and Roberts, G. W. (1993). Betaamyloid precursor protein (beta
APP) as a marker for axonal injury after head injury. Neurosci. Lett. 160, 139-144. doi: 10.1016/03043940(93)90398-5

Giunta, B., Fernandez, F., Nikolic, W. V., Obregon, D., Rrapo, E., Town, T., et al. (2008). Inflammaging as a prodrome to Alzheimer's disease. J. Neuroinflamm. 5:51. doi: 10.1186/ 1742-2094-5-51

Goldstein, L. E., Fisher, A. M., Tagge, C. A., Zhang, X. L., Velisek, L., Sullivan, J. A., et al. (2012). Chronic traumatic encephalopathy in blastexposed military veterans and a blast neurotrauma mouse model. Sci. Transl. Med. 4:134ra160.

Gorrie, C., Oakes, S., Duflou, J., Blumbergs, P., and Waite, P. M. (2002). Axonal injury in children after motor vehicle crashes: extent, distribution, and size of axonal swellings using beta-APP immunohistochemistry. J. Neurotrauma 19, 1171-1182. doi: 10.1089/ 08977150260337976

Graham, D. I., Gentleman, S. M., Lynch, A., and Roberts, G. W. (1995). Distribution of betaamyloid protein in the brain following severe head injury. Neuropathol. Appl. Neurobiol. 21, 27-34. doi: 10.1111/j.1365-2990. 1995.tb01025.x

Graham, D. I., Gentleman, S. M., Nicoll, J. A., Royston, M. C., McKenzie, J. E., Roberts, G. W., et al. (1996). Altered beta-APP metabolism after head injury and its relationship to the aetiology of Alzheimer's disease. Acta Neurochir. Suppl. 66, 96-102.

Hamberger, A., Huang, Y. L., Zhu, H., Bao, F., Ding, M., Blennow, K., et al. (2003). Redistribution of neurofilaments and accumulation of beta-amyloid protein after brain injury by rotational acceleration of the head. J. Neurotrauma 20, 169-178. doi: $\quad 10.1089 / 0897715036054$ 7080

Hartman, R. E., Laurer, H., Longhi, L., Bales, K. R., Paul, S. M., McIntosh, T. K., et al. (2002). Apolipoprotein E4 influences amyloid deposition but not cell loss after traumatic brain injury in a mouse model of Alzheimer's disease. J. Neurosci. 22, 10083-10087.

Hausmann, R., Biermann, T., Wiest, I., Tubel, J., and Betz, P. (2004). Neuronal apoptosis following human brain injury. Int. J. Legal Med. 118, 32-36. doi: 10.1007/ s00414-003-0413-4

Hickman, S. E., Allison, E. K., and El Khoury, J. (2008). Microglial dysfunction and defective beta-amyloid clearance pathways in aging Alzheimer's disease mice. J. Neurosci. 28, 8354-8360. doi: 10.1523/JNEUROSCI.0616-08. 2008

Hoshino, S., Tamaoka, A., Takahashi, M., Kobayashi, S., Furukawa, T., Oaki, Y., et al. (1998). Emergence of immunoreactivities for phosphorylated tau and amyloid-beta protein in chronic stage of fluid percussion injury in rat brain. Neuroreport 9, 1879-1883. doi: 10.1097/00001756-19980601000039

Hutchison, J. S., Derrane, R. E., Johnston, D. L., Gendron, N., Barnes, D., Fliss, H., et al. (2001) Neuronal apoptosis inhibitory protein expression after traumatic brain injury in the mouse. J. Neurotrauma 18, 1333-1347. doi: $10.1089 / 0897715015272$ 5632

Hyder, A. A., Wunderlich, C. A., Puvanachandra, P., Gururaj, G., and Kobusingye, O. C. (2007). The impact of traumatic brain injuries: a global perspective. Neuro Rehabil. 22, 341-353.

Ikonomovic, M. D., Uryu, K., Abrahamson, E. E., Ciallella, J. R., Trojanowski, J. Q., Lee, V. M. et al. (2004). Alzheimer's pathology in human temporal cortex surgically excised after severe brain injury. Exp. Neurol. 190, 192-203. doi: $\quad 10.1016 / j . e x p n e u r o l .2004$. 06.011

Israelsson, C., Bengtsson, H., Kylberg, A., Kullander, K., Lewen, A., Hillered, L., et al. (2008). Distinct cellular patterns of upregulated chemokine expression supporting a prominent inflammatory role in traumatic brain injury. J. Neurotrauma 25, 959-974. doi: 10.1089/neu.2008 0562

Iwata, A., Chen, X. H., McIntosh, T. K., Browne, K. D., and Smith, D. H. (2002). Long-term accumulation of amyloid-beta in axons following brain trauma without persistent upregulation of amyloid precursor protein genes. J. Neuropathol. Exp. Neurol. 61, 1056-1068.

Johnson, V. E., Stewart, J. E., Begbie, F. D., Trojanowski, J. Q., Smith, D. H., and Stewart, W. (2013). Inflammation and white matter degeneration persist for years after a single traumatic brain injury. Brain 136(Pt 1), 28-42.

Johnson, V. E., Stewart, W., and Smith, D. H. (2012). Widespread tau and amyloid-beta pathology many years after a single traumatic brain injury in humans. Brain Pathol. 22, 
142-149. doi: 10.1111/j.1750-3639. 2011.00513.x

Kane, M. D., Lipinski, W. J., Callahan, M. J., Bian, F., Durham, R. A., Schwarz, R. D., et al. (2000). Evidence for seeding of beta amyloid by intracerebral infusion of Alzheimer brain extracts in beta -amyloid precursor proteintransgenic mice. J. Neurosci. 20, 3606-3611.

Knoblach, S. M., and Faden, A. I. (1998). Interleukin-10 improves outcome and alters proinflammatory cytokine expression after experimental traumatic brain injury. Exp. Neurol. 153, 143-151. doi: 10.1006/exnr.1998.6877

Koshinaga, M., Katayama, Y., Fukushima, M., Oshima, H., Suma, T., and Takahata, T. (2000). Rapid and widespread microglial activation induced by traumatic brain injury in rat brain slices. J. Neurotrauma 17, 185-192. doi: 10.1089/neu.2000. 17.185

Kotapka, M. J., Graham, D. I., Adams, J. H., and Gennarelli, T. A. (1992). Hippocampal pathology in fatal non-missile human head injury. Acta Neuropathol. 83, 530-534. doi: 10.1007/BF00310031

Lewen, A., Li, G. L., Nilsson, P., Olsson, Y., and Hillered, L. (1995). Traumatic brain injury in rat produces changes of beta-amyloid precursor protein immunoreactivity. Neuroreport 6, 357-360. doi: 10.1097/00001756-19950100000032

Lewen, A., Sugawara, T., Gasche, Y., Fujimura, M., and Chan, P. H. (2001). Oxidative cellular damage and the reduction of APE/Ref-1 expression after experimental traumatic brain injury. Neurobiol. Dis. 8, 380-390. doi: 10.1006/nbdi.2001. 0396

Liao, Y. F., Wang, B. J., Cheng, H. T., Kuo, L. H., and Wolfe, M. S. (2004). Tumor necrosis factor-alpha, interleukin-1beta, and interferongamma stimulate gammasecretase-mediated cleavage of amyloid precursor protein through a JNK-dependent MAPK pathway. J. Biol. Chem. 279, 49523-49532. doi: 10.1074/jbc.M402034200

Liou, A. K., Clark, R. S., Henshall, D. C., Yin, X. M., and Chen, J. (2003). To die or not to die for neurons in ischemia, traumatic brain injury and epilepsy: a review on the stress-activated signaling pathways and apoptotic pathways. Prog. Neurobiol. 69, 103-142. doi: 10.1016/S03010082(03)00005-4
Loane, D. J., Pocivavsek, A., Moussa, C. E., Thompson, R., Matsuoka, Y., Faden, A. I., et al. (2009). Amyloid precursor protein secretases as therapeutic targets for traumatic brain injury. Nat. Med. 15, 377-379. doi: 10.1038/ nm. 1940

Luth, H. J., Holzer, M., Gartner, U., Staufenbiel, M., and Arendt, T. (2001). Expression of endothelial and inducible NOS-isoforms is increased in Alzheimer's disease, in APP23 transgenic mice and after experimental brain lesion in rat: evidence for an induction by amyloid pathology. Brain Res. 913, 57-67. doi: 10.1016/S0006-8993 (01)02758-5

Mantyla, M. (1981). Post-traumatic cerebral atrophy. A study on braininjured veterans on the Finnish wars of 1939-40 and 1941-45. Ann. Clin. Res. 13, 1-47.

Maxwell, W. L., Domleo, A., McColl, G., Jafari, S. S., and Graham, D. I. (2003). Post-acute alterations in the axonal cytoskeleton after traumatic axonal injury. J. Neurotrauma 20, 151-168. doi: $\quad 10.1089 / 0897715036054$ 7071

Maxwell, W. L., MacKinnon, M. A., Stewart, J. E., and Graham, D. I. (2010). Stereology of cerebral cortex after traumatic brain injury matched to the Glasgow outcome score. Brain 133(Pt 1), 139-160. doi: 10.1093/brain/ awp264

McKee, A. C., Gavett, B. E., Stern, R. A., Nowinski, C. J., Cantu, R. C., Kowall, N. W., et al. (2010). TDP-43 proteinopathy and motor neuron disease in chronic traumatic encephalopathy. J. Neuropathol. Exp. Neurol. 69, 918-929. doi: $\quad 10.1097 /$ NEN.0b013e3181 ee7d85

McKee, A. C., Stein, T. D., Nowinski, C. J., Stern, R. A., Daneshvar, D. H., Alvarez, V. E., et al. (2013). The spectrum of disease in chronic traumatic encephalopathy. Brain 136(Pt 1), 43-64.

McKenzie, J. E., Roberts, G. W., and Royston, M. C. (1996). Comparative investigation of neurofibrillary damage in the temporal lobe in Alzheimer's disease, Down's syndrome and dementia pugilistica. Neurodegeneration 5, 259-264. doi: 10.1006/neur.1996.0034

Meyer-Luehmann,

M., Coomaraswamy, J., Bolmont, T., Kaeser, S., Schaefer, C., Kilger, E., et al. (2006). Exogenous induction of cerebral beta-amyloidogenesis is governed by agent and host. Science
313, 1781-1784. doi: 10.1126/ science. 1131864

Miller, G. (2012). Neuropathology. Blast injuries linked to neurodegeneration in veterans. Science 336 790-791. doi: 10.1126/science.336. 6083.790

Morales, D. M., Marklund, N., Lebold, D., Thompson, H. J., Pitkanen, A., Maxwell, W. L., et al. (2005). Experimental models of traumatic brain injury: do we really need to build a better mousetrap? Neuroscience 136, 971-989. doi: 10.1016/j.neuroscience.2005. 08.030

Morganti-Kossmann, M. C., Rancan, M., Otto, V. I., Stahel, P. F., and Kossmann, T. (2001). Role of cerebral inflammation after traumatic brain injury: a revisited concept. Shock 16, 165-177. doi: 10.1097/ 00024382-200116030-00001

Morganti-Kossmann, M. C., Satgunaseelan, L., Bye, N. and Kossmann, T. (2007). Modulation of immune response by head injury. Injury 38 , 1392-1400. doi: 10.1016/j.injury. 2007.10.005

Nadler, Y., Alexandrovich, A., Grigoriadis, N., Hartmann, T. Rao, K. S., Shohami, E., et al. (2008). Increased expression of the gamma-secretase components presenilin-1 and nicastrin in activated astrocytes and microglia following traumatic brain injury. Glia 56, 552-567. doi: 10.1002/glia. 20638

Nagamoto-Combs, K., and Combs, C. K. (2010). Microglial phenotype is regulated by activity of the transcription factor, NFAT (nuclear factor of activated $\mathrm{T}$ cells). J. Neurosci. 30, 9641-9646.

Nagamoto-Combs, K., McNeal, D. W., Morecraft, R. J., and Combs, C. K. (2007). Prolonged microgliosis in the rhesus monkey central nervous system after traumatic brain injury. J. Neurotrauma 24, 1719-1742. doi: 10.1089/neu.2007. 0377

Nathoo, N., Narotam, P. K., Agrawal, D. K., Connolly, C. A., van Dellen, J. R., Barnett, G. H., et al. (2004). Influence of apoptosis on neurological outcome following traumatic cerebral contusion. J. Neurosurg. 101, 233-240. doi: $\quad 10.3171 /$ ins.2004.101.2. 0233

Ng, I., Yeo, T. T., Tang, W. Y., Soong, R., Ng, P. Y., and Smith, D. R. (2000). Apoptosis occurs after cerebral contusions in humans. Neurosurgery 46 , 949-956.
Njie, E. G., Boelen, E., Stassen, F. R., Steinbusch, H. W., Borchelt, D. R., and Streit, W. J. (2012). Ex vivo cultures of microglia from young and aged rodent brain reveal age-related changes in microglial function. Neurobiol. Aging 33, 195, e191-e112.

O’Dell, D. M., Muir, J. K., Zhang, C., Bareyre, F. M., Saatman, K. E., Raghupathi, R., et al. (2000). Lubeluzole treatment does not attenuate neurobehavioral dysfunction or CA3 hippocampal neuronal loss following traumatic brain injury in rats. Restor. Neurol. Neurosci. 16, 127-134.

Ojo, J. O., Mouzon, B., Greenberg, M. B., Bachmeier, C., Mullan, M., and Crawford, F. (2013). Repetitive mild traumatic brain injury augments tau pathology and glial activation in aged hTau mice. J. Neuropathol. Exp. Neurol. 72, 137-151. doi: 10.1097/ NEN.0b013e3182814cdf

Pierce, J. E., Smith, D. H., Trojanowski, J. Q., and McIntosh, T. K. (1998). Enduring cognitive, neurobehavioral and histopathological changes persist for up to one year following severe experimental brain injury in rats. Neuroscience 87, 359-369. doi: $\quad 10.1016 / S 0306-4522(98)$ 00142-0

Pierce, J. E., Trojanowski, J. Q., Graham, D. I., Smith, D. H., and McIntosh, T. K. (1996). Immunohistochemical characterization of alterations in the distribution of amyloid precursor proteins and beta-amyloid peptide after experimental brain injury in the rat. J. Neurosci. 16, 1083-1090.

Pravdenkova, S. V., Basnakian, A. G., James, S. J., and Andersen, B. J. (1996). DNA fragmentation and nuclear endonuclease activity in rat brain after severe closed head injury. Brain Res. 729, 151-155. doi: $\quad 10.1016 / 0006-8993(96)$ 00222-3

Raghupathi, R., Conti, A. C., Graham, D. I., Krajewski, S., Reed, J. C., Grady, M. S., et al. (2002). Mild traumatic brain injury induces apoptotic cell death in the cortex that is preceded by decreases in cellular Bcl-2 immunoreactivity. Neuroscience 110, 605-616. doi: $\quad 10.1016 / S 0306-4522(01)$ 00461-4

Ramlackhansingh, A. F., Brooks, D. J., Greenwood, R. J., Bose, S. K. Turkheimer, F. E., Kinnunen, K. M., et al. (2011). Inflammation after trauma: microglial activation and traumatic brain injury. Ann. 
Neurol. 70, 374-383. doi: 10.1002/ ana. 22455

Rezai-Zadeh, K., Gate, D., and Town, T. (2009). CNS infiltration of peripheral immune cells: D-Day for neurodegenerative disease? J. Neuroimmune Pharmacol. 4, 462-475. doi: 10.1007/s11481-0099166-2

Rink, A., Fung, K. M., Trojanowski, J. Q., Lee, V. M., Neugebauer, E., and McIntosh, T. K. (1995). Evidence of apoptotic cell death after experimental traumatic brain injury in the rat. Am. J. Pathol. 147, 1575-1583.

Roberts, G. W., Gentleman, S. M., Lynch, A., and Graham, D. I. (1991). beta A4 amyloid protein deposition in brain after head trauma. Lancet 338, 1422-1423. doi: 10.1016/01406736(91)92724-G

Roberts, G. W., Gentleman, S. M., Lynch, A., Murray, L., Landon, M., and Graham, D. I. (1994). Beta amyloid protein deposition in the brain after severe head injury: implications for the pathogenesis of Alzheimer's disease. J. Neurol. Neurosurg. Psychiatry 57, 419-425. doi: 10.1136/jnnp.57. 4.419

Rogers, J. T., Bush, A. I., Cho, H. H., Smith, D. H., Thomson, A. M., Friedlich, A. L., et al. (2008). Iron and the translation of the amyloid precursor protein (APP) and ferritin mRNAs: riboregulation against neural oxidative damage in Alzheimer's disease. Biochem. Soc. Trans. 36( $\mathrm{Pt} 6)$, 1282-1287. doi: 10.1042/BST03 61282

Rothwell, N. (2003). Interleukin-1 and neuronal injury: mechanisms, modification, and therapeutic potential. Brain Behav. Immun. 17, 152-157. doi: 10.1016/S0889-1591 (02)00098-3

Schmidt, M. L., Zhukareva, V., Newell, K. L., Lee, V. M., and Trojanowski, J. Q. (2001). Tau isoform profile and phosphorylation state in dementia pugilistica recapitulate Alzheimer's disease. Acta Neuropathol. 101, 518-524.

Selkoe, D. J. (2001). Alzheimer's disease: genes, proteins, and therapy. Physiol. Rev. 81, 741-766.

Sherriff, F. E., L. R. Bridges, and Sivaloganathan, S. (1994). Early detection of axonal injury after human head trauma using immunocytochemistry for betaamyloid precursor protein. Acta Neuropathol. 87, 55-62. doi: 10.1007/BF00386254

Shitaka, Y., Tran, H. T., Bennett, R. E., Sanchez, L., Levy, M. A., Dikranian,
K., et al. (2011). Repetitive closedskull traumatic brain injury in mice causes persistent multifocal axonal injury and microglial reactivity. J. Neuropathol. Exp. Neurol. 70, 551-567. doi: 10.1097/NEN. 0b013e31821f891f

Shively, S., Scher, A. I., Perl, D. P., and Diaz-Arrastia, R. (2012). Dementia resulting from traumatic brain injury: what is the pathology? Arch Neurol. 69, 1245-1251.

Sinson, G., Perri, B. R., Trojanowski, J. Q., Flamm, E. S., and McIntosh, T. K. (1997). Improvement of cognitive deficits and decreased cholinergic neuronal cell loss and apoptotic cell death following neurotrophin infusion after experimental traumatic brain injury. J. Neurosurg. 86, 511-518. doi: 10.3171/jns.1997.86. 3.0511

Sivanandam, T. M., and Thakur, M. K. (2012). Traumatic brain injury: a risk factor for Alzheimer's disease. Neurosci. Biobehav. Rev. 36, 1376-1381. doi: 10.1016/j. neubiorev.2012.02.013

Smith, D. H., Chen, X. H., Iwata, A., and Graham, D. I. (2003a). Amyloid beta accumulation in axons after traumatic brain injury in humans. J. Neurosurg. 98, 1072-1077. doi: 10.3171/jns.2003.98.5.1072

Smith, C., Graham, D. I., et al. (2003b). Tau immunohistochemistry in acute brain injury. Neuropathol. Appl. Neurobiol. 29, 496-502. doi: 10.1046/j.1365-2990.2003.00488.x

Smith, D. H., Chen, X. H., Nonaka, M., Trojanowski, J. Q., Lee, V. M., Saatman, K. E., et al. (1999). Accumulation of amyloid beta and tau and the formation of neurofilament inclusions following diffuse brain injury in the pig. J. Neuropathol. Exp. Neurol. 58, 982-992. doi: 10.1097/00005072199909000-00008

Smith, D. H., Chen, X. H., Pierce, J. E., Wolf, J. A., Trojanowski, J. Q., Graham, D. I., et al. (1997). Progressive atrophy and neuron death for one year following brain trauma in the rat. J. Neurotrauma 14, 715-727. doi: 10.1089/neu.1997. 14.715

Smith, D. H., Nakamura, M., McIntosh, T. K., Wang, J., Rodriguez, A., Chen, X. H., et al. (1998). Brain trauma induces massive hippocampal neuron death linked to a surge in beta-amyloid levels in mice overexpressing mutant amyloid precursor protein. Am. J. Pathol. 153, 1005-1010. doi: $\quad 10.1016 /$ S0002-9440(10) 65643-X
Stern, R. A., Riley, D. O., Daneshvar, D. H., Nowinski, C. J., Cantu, R. C., and McKee, A. C. (2011) Long-term consequences of repetitive brain trauma: chronic traumatic encephalopathy. PM R 3(10 Suppl 2), S460-S467. doi: 10.1016/ j.pmrj.2011.08.008

Stone, J. R., Okonkwo, D. O., Singleton, R. H., Mutlu, L. K., Helm, G. A., and Povlishock, J. T. (2002). Caspase-3-mediated cleavage of amyloid precursor protein and formation of amyloid Beta peptide in traumatic axonal injury. J. Neurotrauma 19, 601-614. doi: 10.1089/089771502753754073

Stover, J. F., Schoning, B., Beyer, T. F., Woiciechowsky, C., and Unterberg, A. W. (2000). Temporal profile of cerebrospinal fluid glutamate, interleukin-6, and tumor necrosis factor-alpha in relation to brain edema and contusion following controlled cortical impact injury in rats. Neurosci. Lett. 288, 25-28. doi: 10.1016/S0304-3940(00)01187-3

Sutton, R. L., Lescaudron, L., and Stein D. G. (1993). Unilateral cortical contusion injury in the rat: vascular disruption and temporal development of cortical necrosis. J. Neurotrauma 10, 135-149. doi: 10.1089/neu.1993.10.135

Szczygielski, J., Mautes, A., Steudel, W. I., Falkai, P., Bayer, T. A., and Wirths, O. (2005). Traumatic brain injury: cause or risk of Alzheimer's disease? A review of experimental studies. J. Neural Transm. 112 1547-1564. doi: 10.1007/s00702005-0326-0

Tamagno, E., Guglielmotto, M. Bardini, P., Santoro, G., Davit, A., Di Simone, D., et al. (2003). Dehydroepiandrosterone reduces expression and activity of BACE in NT2 neurons exposed to oxidative stress. Neurobiol. Dis. 14, 291-301. doi: $\quad 10.1016 /$ S0969-9961(03) 00131-1

Tehranian, R., Rose, M. E., Vagni, V., Griffith, R. P., Wu, S., Maits, S., et al. (2006). Transgenic mice that overexpress the anti-apoptotic Bcl-2 protein have improved histological outcome but unchanged behavioral outcome after traumatic brain injury. Brain Res. 1101, 126-135. doi: $\quad 10.1016 /$ j.brainres.2006 05.049

Tokuda, T., Ikeda, S., Yanagisawa, N., Ihara, Y., and Glenner, G. G. (1991). Re-examination of exboxers' brains using immunohistochemistry with antibodies to amyloid beta-protein and tau protein. Acta Neuropathol. 82, 280-285. doi: 10.1007/BF00308813
Town, T. (2009). Alternative Abeta immunotherapy approaches for Alzheimer's disease. CNS Neurol. Disord. Drug Targets 8, 114-127. doi: 10.2174/187152709787847306

Town, T., Laouar, Y., Pittenger, C., Mori, T., Szekely, C. A., Tan, J., et al. (2008). Blocking TGFbeta-Smad2/3 innate immune signaling mitigates Alzheimerlike pathology. Nat. Med. 14, 681-687.

Town, T., Nikolic, V., and Tan, J. (2005). The microglial "activation" continuum: from innate to adaptive responses. J. Neuroinflammation 2: 24. doi: 10.1186/1742-2094$2-24$

Tran, H. T., LaFerla, F. M., Holtzman, D. M., and Brody, D. L. (2011a). Controlled cortical impact traumatic brain injury in $3 \times \mathrm{Tg}-\mathrm{AD}$ mice causes acute intra-axonal amyloid-beta accumulation and independently accelerates the development of tau abnormalities. J. Neurosci. 31, 9513-9525. doi: 10.1523/JNEUROSCI.0858-11. 2011

Tran, H. T., Sanchez, L., Esparza, T. J., and Brody, D. L. (2011b). Distinct temporal and anatomical distributions of amyloid-beta and tau abnormalities following controlled cortical impact in transgenic mice. PLoS ONE 6:e25475. doi: 10.1371/ journal.pone.0025475

Tyor, W. R., Avgeropoulos, N., Ohlandt, G., and Hogan, E. L. (2002). Treatment of spinal cord impact injury in the rat with transforming growth factor-beta. J. Neurol. Sci. 200(1-2), 33-41. doi: $\quad 10.1016 / \mathrm{S} 0022-510 \mathrm{X}(02)$ 00113-2

Uryu, K., Chen, X. H., Martinez, D., Browne, K. D., Johnson, V. E., Graham, D. I., et al. (2007). Multiple proteins implicated in neurodegenerative diseases accumulate in axons after brain trauma in humans. Exp. Neurol. 208, 185-192. doi: 10.1016/ j.expneurol.2007.06.018

Uryu, K., Laurer, H., McIntosh, T., Pratico, D., Martinez, D., Leight, S., et al. (2002). Repetitive mild brain trauma accelerates Abeta deposition, lipid peroxidation, and cognitive impairment in a transgenic mouse model of Alzheimer amyloidosis. J. Neurosci. 22, 446-454.

Walker, L. C., Callahan, M. J., Bian, F., Durham, R. A., Roher, A. E., and Lipinski, W. J. (2002). Exogenous induction of cerebral beta-amyloidosis in betaAPPtransgenic mice. Peptides 23, 1241-1247. doi: 10.1016/S01969781(02)00059-1 
Weitz, T. M., and Town, T. (2012). Microglia in Alzheimer's Disease: It's All About Context. Int. J. Alzheimers Dis. 2012: 314185. doi: 10.1155/2012/314185

Yakovlev, A. G., Knoblach, S. M., Fan, L., Fox, G. B., Goodnight, R., and Faden, A. I. (1997). Activation of CPP32-like caspases contributes to neuronal apoptosis and neurological dysfunction after traumatic brain injury. J. Neurosci. 17, 7415-7424.

Yatsiv, I., Grigoriadis, N., Simeonidou, C., Stahel, P. F., Schmidt, O. I., Alexandrovitch, A. G., et al. (2005). Erythropoietin is neuroprotective, improves functional recovery, and reduces neuronal apoptosis and inflammation in a rodent model of experimental closed head injury. FASEB J. 19, 1701-1703.

Yoshiyama, Y., Uryu, K., Higuchi, M., Longhi, L., Hoover, R., Fujimoto, S., et al. (2005). Enhanced neurofibrillary tangle formation, cerebral atrophy, and cognitive deficits induced by repetitive mild brain injury in a transgenic tauopathy mouse model. J. Neurotrauma 22, 1134-1141. doi: $10.1089 /$ neu.2005.22.1134

Yu, F., Zhang, Y., and Chuang, D. M. (2012). Lithium reduces BACE1 overexpression, beta amyloid accumulation, and spatial learning deficits in mice with traumatic brain injury. J. Neurotrauma 29,
2342-2351. doi: 10.1089/neu.2012. 2449

Zemlan, F. P., Rosenberg, W. S., Luebbe, P. A., Campbell, T. A., Dean, G. E., Weiner, N. E., et al. (1999). Quantification of axonal damage in traumatic brain injury: affinity purification and characterization of cerebrospinal fluid tau proteins. J. Neurochem. 72, 741-750. doi: $\quad 10.1046 / j .1471-4159.1999$. 0720741.x

Conflict of Interest Statement: The authors declare that the research was conducted in the absence of any commercial or financial relationships that could be construed as a potential conflict of interest.
Received: 04 April 2013; paper pending published: 24 April 2013; accepted: 13 June 2013; published online: 11 July 2013.

Citation: Breunig JJ, Guillot-Sestier M-V and Town T (2013) Brain injury, neuroinflammation and Alzheimer's disease. Front. Aging Neurosci. 5:26. doi: 10.3389/fnagi.2013.00026

Copyright (c) 2013 Breunig, Guillot-Sestier and Town. This is an open-access article distributed under the terms of the Creative Commons Attribution License, which permits use, distribution and reproduction in other forums, provided the original authors and source are credited and subject to any copyright notices concerning any third-party graphics etc. 